Florida International University FIU Digital Commons

FIU Electronic Theses and Dissertations

University Graduate School

3-30-2012

\title{
Program Notes: Suite in E Minor and the Aranjuez Concerto
}

Karen Schoenhals

guitaristkaren@aol.com

DOI: $10.25148 /$ etd.FI12050232

Follow this and additional works at: https://digitalcommons.fiu.edu/etd

\section{Recommended Citation}

Schoenhals, Karen, "Program Notes: Suite in E Minor and the Aranjuez Concerto" (2012). FIU Electronic Theses and Dissertations. 626. https://digitalcommons.fiu.edu/etd/626

This work is brought to you for free and open access by the University Graduate School at FIU Digital Commons. It has been accepted for inclusion in FIU Electronic Theses and Dissertations by an authorized administrator of FIU Digital Commons. For more information, please contact dcc@fiu.edu. 


\title{
FLORIDA INTERNATIONAL UNIVERSITY
}

\author{
Miami, Florida
}

PROGRAM NOTES: SUITE IN E MINOR AND THE ARANJUEZ CONCERTO

\author{
A thesis submitted in partial fulfillment of \\ the requirements for the degree of \\ MASTER OF MUSIC \\ by \\ Karen Schoenhals
}

2012 
To: Dean Brian Schriner

College of Architecture and the Arts

This thesis, written by Karen Schoenhals, and entitled Program Notes: Suite in E Minor and the Aranjuez Concerto, having been approved in respect to style and intellectual content, is referred to you for judgment.

We have read this thesis and recommend that it be approved.

David Dolata

$\begin{array}{r}\hline \text { Marcia Littley } \\ \hline \text { Rafael Padron, Major Professor }\end{array}$

Date of Defense: March 30, 2012

The thesis of Karen Schoenhals is approved.

Dean Brian Schriner
College of Architecture and the Arts

Dean Lakshmi N. Reddi University Graduate School

Florida International University, 2012 


\begin{abstract}
OF THE THESIS
PROGRAM NOTES: SUITE IN E MINOR AND THE ARANJUEZ CONCERTO by
\end{abstract}

Karen Schoenhals

Florida International University, 2012

Miami, Florida

Professor Rafael Padron, Major Professor

There were two major works in this classical guitar recital. One was a Baroque suite for organ by the composer Dietrich Buxtehude that had been transcribed for classical guitar. The other, the Aranjuez Concerto, was a full concerto, composed for classical guitar and orchestra, by Joaquin Rodrigo. The pieces were performed with a piano reduction of the orchestral part. These two pieces represented a wide range of musical styles that can be expressed through the classical guitar $\neg$ a more transparent solo composition, as well as an entire concerto for guitar and accompaniment. 


\section{TABLE OF CONTENTS}

CHAPTER

PAGE

Suite in E Minor by Dietrich Buxtehude................................................................. 1

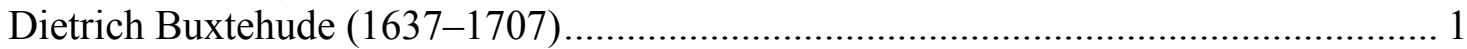

Baroque Characteristics of the Suite in E Minor.......................................................... 2

Concierto de Aranjuez by Joaquin Rodrigo................................................................ 5

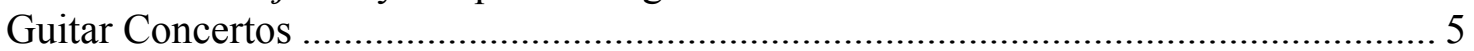

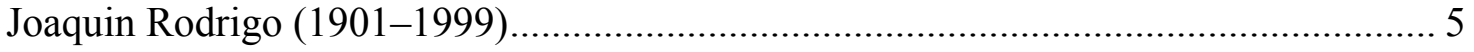

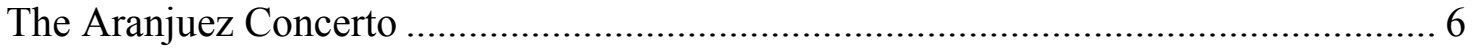

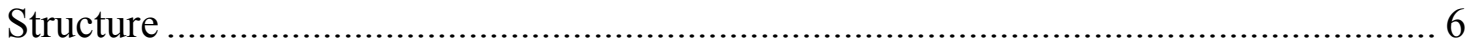




\section{LIST OF FIGURES}

FIGURE

PAGE

1. Structure of the Courante................................................

2. Structure of the Allemande, Sarabande, and Gigue.............................

3. Counterpoint in the Allemande...........................................

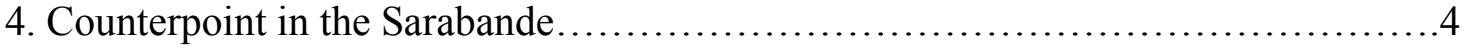

5. Hemiola in the first movement of the Aranjuez..................................

6. Rubato effect in the second movement of the Aranjuez.........................8

7. Metric alternations in the third movement of the Aranjuez........................8 


\section{Suite in E Minor by Dietrich Buxtehude}

Dietrich Buxtehude (1637-1707)

Dietrich Buxtehude considered Denmark his native country, although there are no documents verifying his birthplace. His father, Johannes, an organist, was Buxtehude's music teacher. ${ }^{1}$ In 1667 , Buxtehude was hired as the organist at the Marienkirche at Lübeck, one of the most important churches in the Germanic Lutheran states. In Lübeck he achieved a large measure of his fame by directing a music series dedicated to the performance of sacred dramatic works called "Abendmusiken," which became as popular as operas in the region. Buxtehude's compositions include both sacred and secular works for voice, keyboard (presumably organ), viol da gamba, harpsichord, violin, and chamber ensemble. He wrote nineteen keyboard suites, including the Suite in E Minor performed on this recital.

Supposedly, Buxtehude did not publish his suites for public consumption, The original manuscript of his suites, written in organ tablature, is located in the Kongelige Bibliotek of Copenhagen. ${ }^{2}$ On the accompanying compact disc, I perform the transcription for guitar by Julian Bream, one of the world's most revered classical guitarists and lutenists.

Buxtehude is known for his profound influence on Johann Sebastian Bach. In 1705 at the age of 20, Bach, walked 250 miles to study with Buxtehude in Lübeck. He stayed for four months, learning Buxtehude's compositional techniques and specifically, his use of counterpoint. Bach's obituary expresses his opinion of Buxtehude as a "model in the

\footnotetext{
${ }^{1}$ Kerala J. Snyder, "Buxtehude, Dieterich." Grove Music Online. Oxford Music Online, www.oxfordmusiconline.com/subscriber/article/grove/music/04477 (accessed February 19, 2012).

${ }^{2}$ Kerala J. Snyder, "Buxtehude, Dieterich."
} 
art of the organ." ${ }^{\prime 3}$ The story of Bach's trip to study with Buxtehude is even more amazing when one considers that it was common at the time for musical craftsmanship to be primarily passed down within individual families. For example, in Bach's own family, Johann Christoph Bach taught his son, J. S. Bach, who in turn taught his own sons, as well as his nephews. It was uncommon for musicians to study outside their musical family, let alone travel far from their region. ${ }^{4}$

\section{Baroque Characteristics of the Suite in E Minor}

The ordering of dance movements in this suite is typical of the Baroque era:

Allemande, Courante, Sarabande, and Gigue. Each movement is organized as a continuous binary form. The Courante exhibits the following form:
A
B
i $\rightarrow$ III $: \|:$ III $\quad \rightarrow$ i [PAC] [PAC] $($ PAC $=$ perfect authentic cadence $)$

\section{Figure 1 Structure of the Courante.}

\footnotetext{
${ }^{3}$ Kerala J. Snyder,"Buxtehude, Dieterich."

${ }^{4}$ Christoph Wolff, "Bach." Grove Music Online. Oxford Music Online, www.oxfordmusiconline.com/subscriber/article/grove/music/40023pg2 (accessed February 20, 2012).
} 
The remaining movements do not modulate in the first section but rather end on half cadences in the home key, with the conventional modulation to the relative major pushed forward to the B section:
A
B
i $\quad \rightarrow$ V : $\|: \rightarrow$ III $\quad \rightarrow$ i
$[\mathrm{HC}] \quad[\mathrm{PAC}] \quad[\mathrm{PAC}]$
$(\mathrm{HC}=$ half cadence $)$

Figure 2 Structure of the Allemande, Sarabande, and Gigue.

Both sections of the binary form are repeated, and in the Baroque period, it was assumed that the performer would add embellishments. In my performance, I add embellishments for the repeat of each section in all four movements.

Buxtehude's suite is characterized by the frequent use of counterpoint. For example, at the beginning of the Allemande, two principal voices emerge. At times, the lower voice imitates the upper one, both in contrary motion (m. 2/2-2/4) and in direct motion (m. 4). 
In the following excerpt, boxes indicate the top voice, and ovals signify the lower voice:
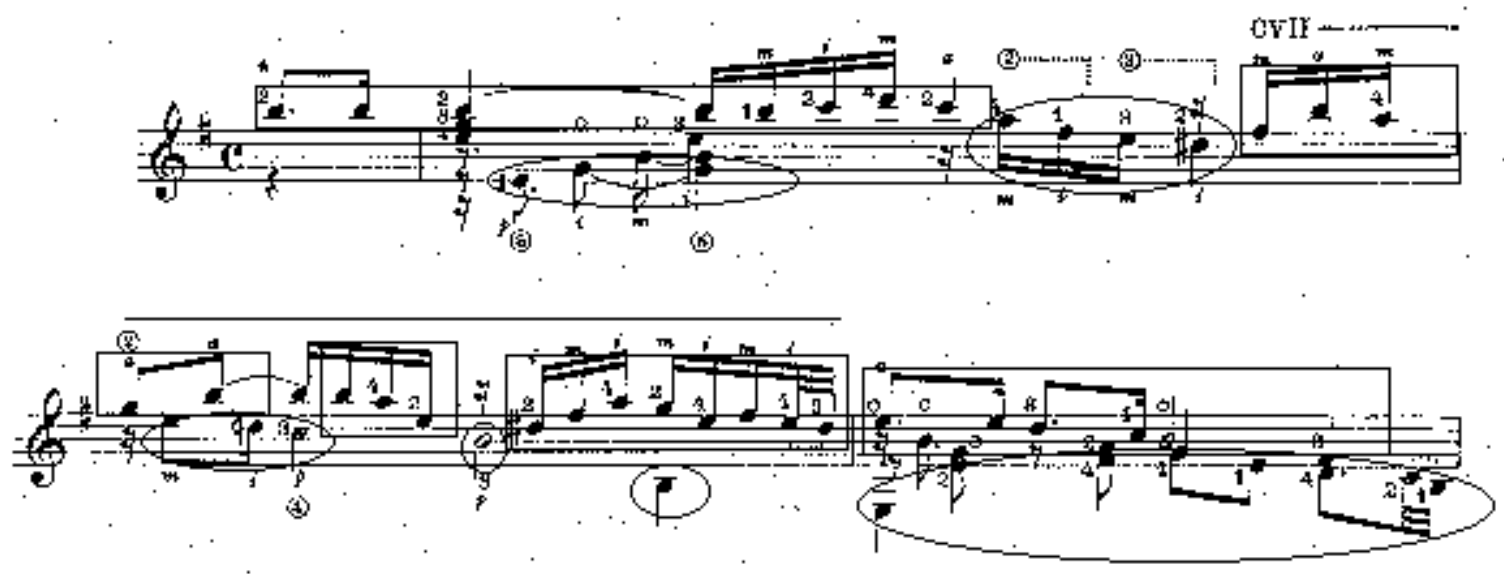

Figure 3 Counterpoint in the Allemande.

This kind of contrapuntal texture continues throughout the work. For example, the Sarabande exhibits a three-part texture: the descending tetrachord from tonic to dominant $(\mathrm{E}-\mathrm{D}-\mathrm{C}-\mathrm{B})$ in the bass, parallel tenths with the bass in the top voice, and the descending third $\mathrm{B}-\mathrm{A}-\mathrm{G}$ in the middle voice:

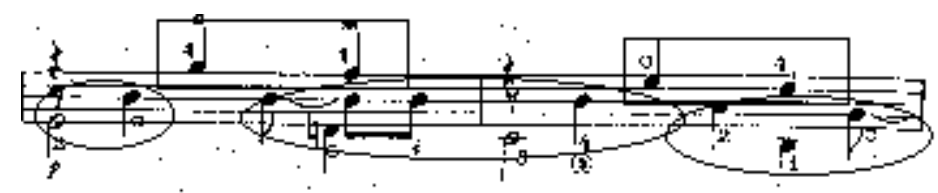

Figure 4 Counterpoint in the Sarabande. 


\section{Concierto de Aranjuez by Joaquin Rodrigo}

\section{Guitar Concertos}

The classical guitar has not had as long of a history as a legitimate classical instrument as that of other classical instruments such as, for example, the violin. For that reason, the classical guitar concerto repertoire is less extensive than those of other classical instruments. The guitar concerto repertoire is expanding, however, as the popularity of the classical guitar grows. In addition, musicologists have discovered guitar concertos dating back as far as the late $18^{\text {th }}$ century. ${ }^{5}$

Joaquin Rodrigo (1901-1999)

When he was three years old, Rodrigo suffered from diphtheria, which caused him to lose nearly all of his eyesight. His blindness was one factor that propelled him toward musical studies. At the age of eight, Rodrigo began studying piano as well as violin, and by the age of 16 , he had already started composing. ${ }^{6}$ He wrote his first compositions for piano, and piano and violin. Throughout his career, we wrote his compositions in Braille, and then dictated them to a copyist. ${ }^{7}$

In addition to the two concertos Rodrigo composed for guitar- the Aranjuez and later the Fantasia para un Gentilhombre-he wrote nine concertos for other instruments, including his first piano concerto, the Concerto Heroice (1933), and a flute concerto, Concierto Pastoral, commissioned by James Galway (1978). Totaling around 170

\footnotetext{
${ }^{5}$ Stanley Yates, "Three Early Guitar Concertos," Soundboard—Guitar Foundation of America 36:3 (2010): 6-11.

${ }^{6}$ www.joaquin-rodrigo.com

${ }^{7}$ David Denton, "Rodrigo: Concertos and Orchestral Works." Fanfare 24:4 (2001): 228-229.
} 
compositions, his works include pieces for orchestra, voice, piano, guitar, ballet, and theater. It was soon after the premier of the Aranjuez that Rodrigo came to be considered one of Spain's most important composers. ${ }^{8}$ Remarkably, Rodrigo himself was not a guitarist, and yet, the Aranjuez is the most beloved guitar concerto in the world. As critic Steven Rings puts it, “The Aranjuez towers over all of the rest of Rodrigo's outputindeed, over the entire Spanish orchestral literature of the 20th century."9

\section{The Aranjuez Concerto}

Rodrigo attributes the inspiration for writing the Aranjuez to the gardens at the Palacio Real de Aranjuez. In his concerto, he tried to capture the fragrance of the flowers, the sounds of the waterfalls, and the bird songs. Rodrigo dedicated the concerto to his friend, guitarist and composer, Regino Sainz de la Maza, who premiered it with the Orquesta Filarmónica de Barcelona on November 9, 1940, and also made the first recording of the work. ${ }^{10}$

\section{Structure}

Rodrigo considered his compositions "faithful to a tradition," and he employed traditional forms in his music. ${ }^{11}$ The first and third movements-Allegro con spirito and Allegro gentile - incorporate folk-style melodies and dance rhythms, with frequent use of

\footnotetext{
${ }^{8}$ Raymond Calcraft, "Rodrigo, Joaquín." Grove Music Online. Oxford Music Online, www.oxfordmusiconline.com/subscriber/article/grove/music/23647 (accessed February 19, 2012).

${ }^{9}$ Steven Rings, "Rodrigo: Concierto de Aranjuez; Fantasia para un Gentilhombre; Concierto Andaluz," American Record Guide 66:2 (2010): 159.

${ }^{10}$ Ricardo Iznaola, "Sainz de la Maza, Regino." Grove Music Online. Oxford Music Online, www.oxfordmusiconline.com/subscriber/article/grove/music/43108 (accessed February 19, 2012).

${ }^{11}$ Raymond Calcraft, "Rodrigo, Joaquín."
} 
hemiola and alternations between duple and triple meter. To most listeners, the melodies sound decidedly Spanish. As scholar David Denton points out, "There is a Spanish element that runs through [Rodrigo's] works, though he places this at the disposal of his music rather than using it as the starting point."'12

The first movement, in $6 / 8$, begins with a motive that is often repeated by the guitar, and echoed by the orchestra. It incorporates a hemiola and sets up the rhythmic syncopation that characterizes the entire movement. In $\mathrm{m} .1$, the $6 / 8$ measure is divided into two beats, and in the next measure it is divided into three:

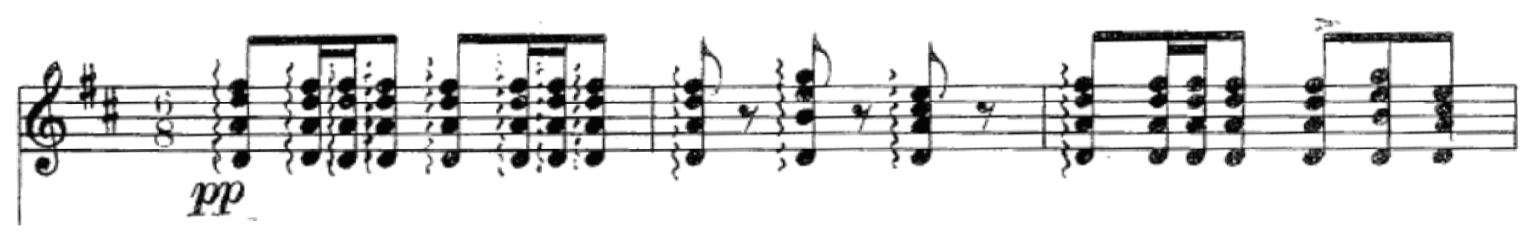

Figure 5 Hemiola in the first movement of the Aranjuez.

The slow, haunting melody of the second movement, Adagio, is recognized even by those who are not otherwise familiar with classical guitar repertoire. Rodrigo wrote the second movement as a lament after his wife miscarried their first baby. ${ }^{13}$ The famous melody is introduced by the orchestra and then echoed by the guitar. Rodrigo's ornamentation emulates the way a flamenco player would improvise around the main melody. If the performer plays the various combinations of triplets and sixteenth notes exactly "as written," the music does indeed sound improvised.

\footnotetext{
${ }^{12}$ David Denton, "Rodrigo: Concertos and Orchestral Works."

${ }^{13}$ Carol A. Hess, “Manuel de Falla: Modernism in Spain, 1898-1936.” Notes 59:2 (Dec., 2002): 342-344.
} 
Rodrigo has essentially written a rubato effect into the score from the start. Consider, for example, the detailed ornamentation around the melody in the following excerpt:

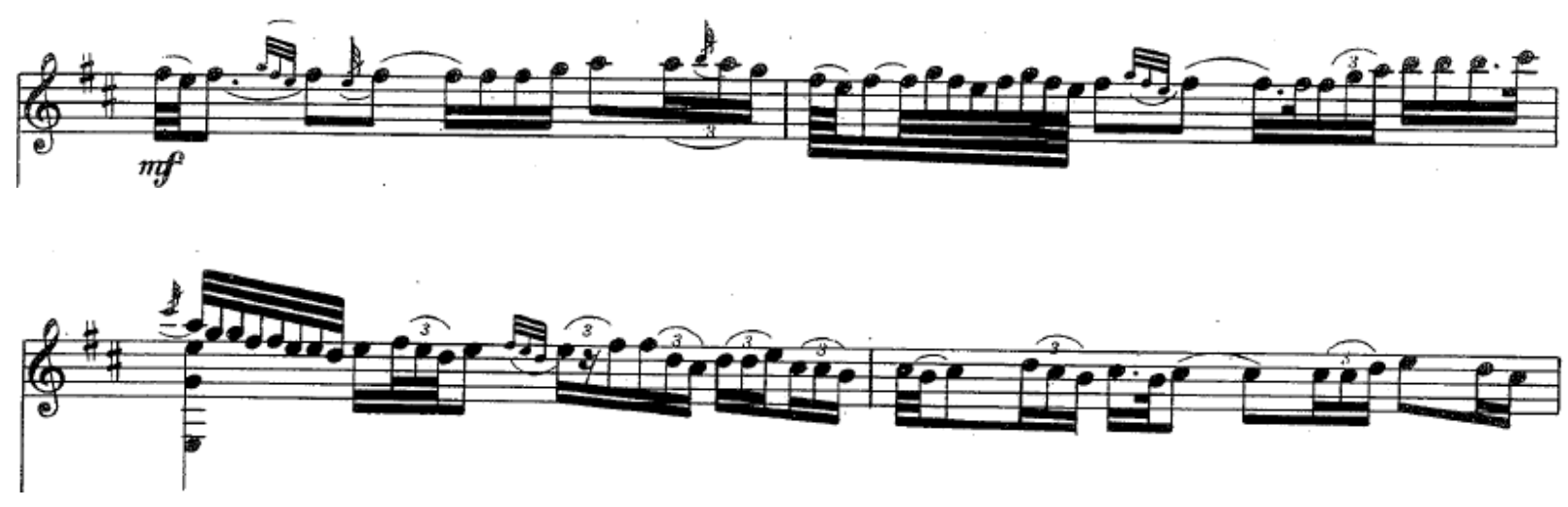

Figure 6 Rubato effect in the second movement of the Aranjuez.

As in the previous movements, the third, with its pervasive metric alternations between $3 / 4$ and 2/4, focuses on rhythmic syncopation. For example, the opening motive consists of one $3 / 4$ measure, followed by three $2 / 4$ measures:

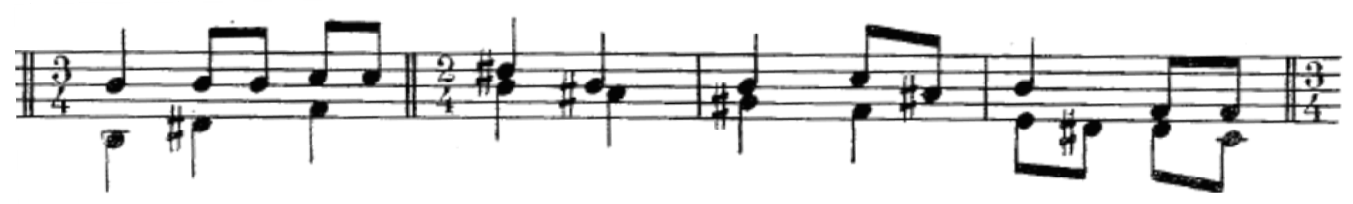

Figure 7 Metric alternations in the third movement of the Aranjuez.

As in the other movements, the orchestra imitates the guitar by repeating the motive.

Later, this specific pattern is broken, and several new combinations emerge (for example, 11 measures of $3 / 4$ followed by 3 measures of $2 / 4$ ). The many permutations of duple and triple measures create continual rhythmic surprises, enlivening this rousing finale. 


\section{References}

Calcraft, Raymond. "Rodrigo, Joaquín." Grove Music Online. Oxford Music Online, www.oxfordmusiconline.com/subscriber/article/grove/music/23647 (accessed February 19, 2012).

Denton, David. "Rodrigo: Concertos and Orchestral Works." Fanfare 24:4 (2001): 228229.

Hess, Carol A. "Manuel de Falla: Modernism in Spain, 1898-1936.” Notes 59:2 (Dec., 2002): 342-344.

Iznaola, Ricardo. "Sainz de la Maza, Regino.” Grove Music Online. Oxford Music Online, www.oxfordmusiconline.com/subscriber/article/grove/music/43108 (accessed February 19, 2012).

Phillips, Peter. "In Memoriam: Joaquín Rodrigo.” The Musical Times 140: 1868 (Autumn, 1999): 6-7.

Snyder, Kerala J. "Buxtehude, Dieterich.” Grove Music Online. Oxford Music Online, www.oxfordmusiconline.com/subscriber/article/grove/music/04477 (accessed February 19, 2012).

Rings, Steven. "Rodrigo: Concierto de Aranjuez; Fantasia para un Gentilhombre; Concierto Andaluz." American Record Guide 66:2 (2003): 159.

Wolff, Christoph, "Bach." Grove Music Online. Oxford Music Online, www.oxfordmusiconline.com/subscriber/article/grove/music/40023pg2 (accessed February 20, 2012).

Yates, Stanley. “Three Early Guitar Concertos.” Soundboard 36:3 (2010): 6-11. 